\title{
AGAMA DAN MULTIKULTUR: PERAN AGAMA MEWUJUDKAN MULTIKULTURALISME DI INDONESIA
}

\author{
Ida Bagus Purnawan \\ Dosen Universitas Udayana, Bali
}

\section{ABSTRACT}

The difference and plurality are necessity condition that must and should be accepted by everyone in his life on earth as human beings. It is a true reality that we know it clearly. How to manage this reality is a longlife problem. One of the efforts is empowering the role of religion. The role of religion in realizing multiculturalism in Indonesia can be reached by building mutual awarenes through the efforts of multiculturalism consciousness transformation into a national identity based on the reality of plurality in Indonesia. The Unity in Diversity as an ideal text always need to be read at any occasion because, in principle, the identity is never final. Likewise, efforts to build a national integration based on multiculturalism by encouraging public awareness using their constitutional rights to assembly, association, and expression in order to fight for the rights of justice, liberty, equality, and actively participated in the development.

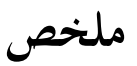

$$
\begin{aligned}
& \text { الفرق والتعددية ضرورة بشرط أن بتب هذه الحالةوأن تكون مقبولة من قبل الجميع في } \\
& \text { حياتم كبشرعلى الأرض. هذا هوالواقع الحقيقي الذي نعرفه بشكل واضح. كيفية }
\end{aligned}
$$

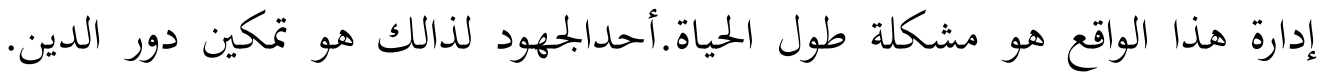

$$
\begin{aligned}
& \text { ويمكن الوصول إلى دور الدين في تحقيق التعددية الثقافية في إندونيسيا من خلال بناء } \\
& \text { الوعي المتبادل بوسيلة جهودتحول الوعي للتعددية الثقافية إلى هوية وطنية على أساس } \\
& \text { واقع التعددية في إندونيسيا. الوحدة في التنوع باعتباره النص المثالي دائما بحاجة إلى }
\end{aligned}
$$

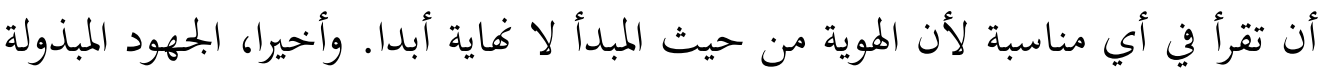




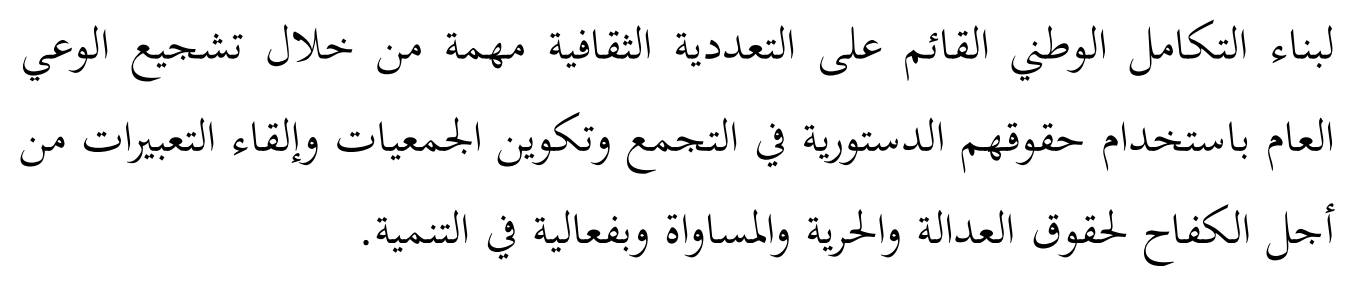

Key words: agama, multikulturalisme, pluralitas, bhinneka tunggal ika.

\section{A. Pendahuluan}

Perbedaan merupakan keniscayaan yang mesti dan harus diterima oleh setiap orang dalam kehidupannya di dunia karena manusia memang merupakan makhluk yang unik dan khas. Hal ini dikatakan oleh Sukarma, ${ }^{1}$ bahkan ditegaskan bahwa keunikan dan kekhasan ini dalam konteks bernegara, berbangsa, dan bermasyarakat akan menimbulkan keberagaman tatanan sosial dan kebudayaan, seperti ditunjukkan oleh Negara Indonesia. Indonesia yang merupakan negara-bangsa terdiri atas beragam etnis, agama, dan bahasa. Bangsa Indonesia mewarisi kemajemukan suku, ras, dan agama dengan perkembangan sejarahnya masing-masing. Dari segi ras, orang Indonesia setidaknya terdiri dari ras Mongoloid-Melayu (Jawa, Sumatera, Kalimantan, Sulawesi), ras Melanesoid (umumnya Indonesia Timur), dan ras Mongoloid (China). Dari segi etnisitas, Indonesia terdiri atas 556 suku bangsa dan 512 bahasa daerah. Dari segi agama, masyarakat Indonesia memiliki enam agama yang secara sah diakui, yaitu Islam, Kristen, Katolik, Hindu, Buddha, dan Kong Hu Cu. Keragaman ini memberikan tugas kepada warga negara, agar kelompok-kelompok agama yang berbeda menemukan jalan hidupnya masing-masing dalam rangka membangun dan menata sistem nilai yang dapat dibagi bersama. Mengingat kepluralistikan masyarakat Indonesia sungguh merupakan tantangan yang menuntut upaya serius dan sungguh-sungguh dalam bentuk transformasi kesadaran keagamaan. Kesadaran keagamaan yang diarahkan sebesar-besarnya mewujudkan multikulturalisme agama di Indonesia. Apalagi agama memang menem-

1 I Wayan Sukarma, 2010. "Multikulturalisme dan Kesatuan Indonesia”, Dharmasmrti, Jurnal Ilmu Agama dan Kebudayaan Hindu, Vol.5-10-2011, Pascasarjana, UNHI: Denpasar, hal. 112. 
pati posisi sentral dalam perencanaan sosial karena agama menjadi inti dari sistem nilai yang dipraktikkan dalam dunia-kehidupan.

Keanekaragaman masyarakat dan kebudayaan Indonesia sesungguhnya bukan masalah baru. Menurut Kusumohamidjojo ${ }^{2}$ sejak sebelum berdirinya sebagai negara merdeka, Indonesia sudah menghadapi persoalan besar yang berkaitan dengan keanekaragaman kebudayaan. Persoalan ini menjadi semakin besar seiring dengan perkembangan zaman dan dinamika sejarah yang menyertainya. Masalah kebhinnekaan itu perlu dibedah secara tuntas, agar masyarakat Indonesia tidak terbuai dan hanyut dalam slogan, seolah-olah keanekaragaman itu lebih merupakan berkah dan bukan pekerjaan rumah. Hal ini dipahami oleh banyak orang Indonesia yang berpikir jernih dan menyadari beratnya tantangan masa depan negara-bangsa ini. Dalam kerangka inilah letak relevansi multikulturalisme untuk membahas masalah kebhinnekaan agama di Indonesia.

Tegasnya, bangsa Indonesia yang multikultur mutlak harus dipandang dari kacamata multikulturalisme, sebagaimana dikemukakan Magnis-Suseno ${ }^{3}$ bahwa Indonesia hanya dapat bersatu, bila pluralitas agama yang menjadi kenyataan sosial dihormati. Artinya, multikulturalisme agama bukan hendak menghilangkan identitas setiap komponen bangsa dan partisipasi agamaagama, tetapi harapannya agar semuanya menjadi warga negara Indonesia tanpa merasa terasing. Sikap saling menghormati identitas masing-masing dan kesediaan untuk tidak memaksakan pandangan agama sendiri tentang "yang baik" kepada siapapun merupakan syarat keberhasilan masa depan Indonesia. Untuk itu, diperlukan transformasi kesadaran multikulturalisme menjadi identitas nasional dan menempatkan agama menjadi fondasi kesatuan bangsa.

Mengingat munculnya fenomena krisis identitas agama yang bertumpu pada kemutlakan ajaran dan primordialisme agama menjadi wacana yang menggelitik minat akademis untuk mempertanyakan kembali tentang apa yang tengah terjadi pada agama. Agama dan etnisitas memunculkan geliat di berbagai belahan dunia sebagai sentimen baru ikatan masyarakat. Tumbuh suburnya religious nationalism dan etno nationalism sebagai identitas-identitas politik baru mengkonstruksi imaji tentang sebuah komunitas agama dan etnisi-

2 Budiono Kusumohamidjojo, 2000, Kebhinnekaan Masyarakat Indonesia: Suatu Problematik Filsafat Kebudayaan, Jakarta: PT. Grasindo, hal. 59-60

3 Franz Magnis Suseno, 2005. Berebut Jiwa Bangsa. Jakarta: Kompas. 
tas yang seolah-olah seragam. ${ }^{4}$ Identitas baru ini memberikan harapan kepada masyarakat akan munculnya kekuatan lain di luar kapitalisme dan modernisme, yaitu agama. Akan tetapi, poros eksklusif yang terbentuk tidak jarang malahan menjadi sumber kekerasan dan konflik sosial sehingga identitas baru ini sekaligus mengerikan. ${ }^{5}$

Dalam konteks ini diperlukan upaya serius dan sungguh-sungguh menangani permasalahan perbedaan termasuk perbedaan sosial yang berlatar belakang agama merupakan wacana menarik diangkat ke permukaan kesadaran melalui mimbar akademik. Menghindari semakin banyaknya muncul permasalahan yang berlatang belakang agama kiranya, perlu dikaji partisipasi agama-agama dalam perubahan sosial dan kebudayaan di Indonesia. Tegasnya, dalam kajian ini agama diperlakukan sebagai aspek yang layak mewujudkan diri ke dalam kesatuan budaya yang bukan monokultur, sebagaimana yang muncul pada masa peluhan tahun belakangan ini. Dalam misi negara-bangsa seperti Indonesia yang senyatanya pluralitas agama memang selayaknya diposisikan pada konsep multikulturalisme. Ke arah inilah pembahasan ini ditujukan, yaitu membangun multikulturalisme agama di Indonesia.

\section{B. Multikulturalisme di Indonesia}

Seseorang baru menyadari keberadaan dirinya sendiri yang paling otentik, ketika berada bersama sesuatu yang lain, barang yang lain, dan orang yang lain. Itulah the others (liyan) dalam konsep multikulutralisme. ${ }^{6}$ Menurut Hefner (2007) bahwa pandangan ini mengacu pada pengalaman Amerika dalam merumuskan kebijakan politik saat negeri itu diserbu para migran dari berbagai bangsa, seperti Eropa, Afrika, dan Amerika Latin. Dengan kebijakan multikultural keragaman dan kebhinnekaan kultur, justru menjadi penguat keberadaan Amerika. Walaupun berbeda latar historisnya, kebhinnekaan etnis,

4 Ahamd Suaedy dkk. 2007. Politisasi Agama dan Konflik Komunal Beberapa Isu Penting di Indonesia. Jakarta: The Wahid Institute, hal. 345

5 Ibid., hal. 346

6 Abdul Munir Mulkhan, 2007. "The Others dalam Bhineka Berbangsa dan Beragama" (Makalah disampaikan pada Seminar Nasional "Multikulturalisme, Agama dan Etnisitas" diselenggarakan oleh Magister Ilmu Agama dan Kebudayaan Universitas Hindu Indonesia di Denpasar tanggal 10 Agustus 2007), hal. 1. 
dan keagamaan di Indonesia bisa menggunakan kerangka pikir multikulturalisme sebagai paradigma kerja. Akan tetapi, perlu disadari bahwa sejarah sosial, budaya, dan keagamaan yang berbeda dengan akar genealogi yang begitu kuat memerlukan strategi berbeda. Fakta sosio-budaya bhinneka dalam keberagamaan bersilangan dengan etnisitas seringkali membuat setiap komunitas budaya dan keagamaan merasa berhak menjadi raja dalam kelompoknya sendiri. Kesadaran primordial ini bukanlah sikap yang salah, bila hal itu disadari menjadi lebih bermakna ketika diletakkan bersama dan dalam keber-liyan-an. Reposisi sekelompok etnis dan keagamaan dalam ruang publik yang terbuka bernama Indonesia akan sulit, bila tidak dimiliki kesadaran akan kebermaknaan liyan tersebut. Formula ini oleh founding fathers dirumuskan dalam Pancasila, walaupun tafsirnya mudah dibelokkan sesuai kepentingan kelompok berbasis primordial tersebut yang sejak lama menjadi akar separatisme yang selalu berulang. ${ }^{7}$

Artinya, membangun kesadaran multikulturalisme dalam sebuah negarabangsa, seperti Indonesia bukanlah upaya yang mudah. Bhinneka Tunggal Ika sebagai teks ideal yang diharapkan dapat menyelesaikan persoalan multikultural di Indonesia, ternyata mengalami penafsiran yang berbeda-beda dalam setiap orde pemerintahan pascakemerdekaan. Pada masa Orde Lama misalnya, Soekarno semboyan Bhinneka Tunggal Ika dijadikan wacana populis untuk menggairahkan semangat persatuan dan kesatuan bangsa. Semangat ini digunakan untuk melawan konstelasi kapitalisme melalui ide nasionalis, agama, dan komunis (Nasakom). Alih-alih memediasi perbedaan, justru ide ini telah mensegmentasi masyarakat Indonesia ke dalam pilihan politik yang berbasis ideologi, seperti PNI (nasionalis), Masyumi dan PSI (agamais atau Islam), dan PKI (komunis). Keberhasilan membangun semangat kebangsaan melalui wacana perlawanan terhadap kolonial, ternyata tidak dibarengi dengan keberhasilan yang sama dalam konsolidasi politik nasional. Sistem politik multipartai yang diterapkan pemerintah Orde Lama telah membawa masyarakat Indonesia pada gejolak politik yang melelahkan dan mencapai puncak ketegangan pada lahirnya tragedi berdarah 30 September $1965 .^{8}$

\footnotetext{
7 Ibid.

8 M. Nurkhoiron, 2007. "Minoritisasi dan Agenda Multikulturalisme di Indonesia: Sebuah Catatan Awal", dalam Hak Minoritas Multikulturalisme dan Dilema Negara Bangsa.
} 
Berbeda dengan Orde Lama, pemerintahan Orde Baru lebih meningkatkan penguasaan dan dominasi massa melalui demobilisasi dan deideologisasi. Praktik pembangunan melahirkan apa yang kemudian dikenal dengan massa mengambang (floating mass). Kebijakan kebudayaan Orde Baru diarahkan untuk memantapkan stabilitas nasional dengan menggiring kebudayaan-kebudayaan daerah menjadi tonggak-tonggak kebudayaan nasional. Hasilnya berupa proses pembakuan sehingga melahirkan efek pada tumbangnya perbedaan budaya dan hancurnya kebudayaan-kebudayaan lokal. Agama dan etnisitas tidak dikelola berdasarkan skema multikultur sehingga sering menjadi sumber perpecahan dan konflik. Pada masa ini pemerintah telah mengambil peran dominan dalam kebijakan multikulturalisme melalui penafsiran tunggal terhadap Pancasila sebagai ideologi negara. Situasi keamanan negara dan masyarakat memang cenderung stabil di permukaan karena pemerintah mengambil sikap represif terhadap munculnya berbagai isu, ideologi, dan ekspresi budaya liyan (the others) yang dianggap menjadi ancaman dan gangguan terhadap stabilitas nasional. Kebijakan ini didukung oleh kerja militeristik yang kuat melalui Dwifungsi ABRI sehingga militer bukan saja hanya mengambil peran sebagai alat keamanan, tetapi juga alat politik pemerintah. ${ }^{9}$

Tumbangnya Orde Baru yang ditandai dengan lengsernya Soeharto telah membawa babak baru dalam multikulturalisme Indonesia. Kebebasan berekspresi dan berpendapat diapresiasi seluas-luasnya oleh kelompok-kelompok yang selama masa pemerintahan Orde Baru tidak memiliki kesempatan untuk berkembang. Dengan memainkan isu identitas, kelompok-kelompok ini mulai membangun eksistensinya. Di beberapa tempat sejumlah kelompok Islam membangun laskar-laskar paramiliter untuk "membela Tuhannya". Demikian juga dengan dipaksakannya penegakkan syariat Islam sebagai bagian dari kebijakan publik di daerah. Hal serupa juga terjadi di Propinsi Papua yang memaksakan diberlakukannya Perda berbasis Injil. ${ }^{10}$

Wacana kedaerahan seperti itu juga muncul di Bali lewat gema wacana Ajeg Bali yang dikumandangkan oleh berbagai lapisan sosial masyarakat

Editor: Marsudi Noorsalim, dkk. Jakarta: Yayasan Interseksi/The Interseksi Foundation, hal. 3

$$
\begin{array}{ll}
{ }_{10} & \text { Ibid. } \\
& \text { Ibid., hal. } 4
\end{array}
$$


Bali. Walaupun wacana ini menunjukkan gejala serupa, tetapi tidak sepenuhnya demikian, seperti ditegaskan oleh Atmadja (2005:3) bahwa wacana Ajeg Bali merupakan gerakan mempertahankan identitas kultural sebagai respons orang Bali terhadap modernisasi dan globalisasi. Boleh jadi, juga prasangka etnis memicu lahirnya wacana Ajeg Bali tersebut sebagai akibat terdesaknya penduduk asli dari dominasi pendatang. Maraknya artikulasi politik identitas yang membangkitkan berbagai aspirasi etnis, agama, dan isu lokalitas memang menjadi sinyal baru bagi dinamika politik mutakhir pascaotoritarianisme Orde Baru. ${ }^{11}$ Kebijakan otonomi daerah yang diharapkan dapat mengatasi masalahmasalah multikulturalisme di Indonesia, ternyata berubah menjadi hiperotonomi sehingga memunculkan politik kedaerahan yang semakin menajamkan prasangka-prasangka etnis, agama, dan lokalitas.

Dengan demikian, dapat dipahami bahwa terdapat perbedaan mencolok antara multikulturalisme sebagai gejala epistemologis dan multikulturalisme sebagai gejala politik. Perbedaan ini menjadi medan perdebatan menarik oleh para teoretisi multikulturalisme. Parekh ${ }^{12}$ salah seorang proponen teori multikulturalisme merekomendasikan bahwa multikulturalisme bukanlah sebuah doktrin politik dengan muatan programatik, tidak pula sebagai sebuah aliran filsafat dengan teori yang khas tentang tempat manusia di dunia, melainkan lebih sebagai sebuah perspektif atau cara melihat kehidupan manusia. Sebaliknya, Liliweri ${ }^{13}$ begitu yakin bahwa multikulturalisme merupakan seperangkat kebijakan pemerintah pusat yang dirancang sedemikian rupa agar seluruh masyarakat dapat memberikan perhatian kepada kebudayaan dari semua kelompok etnik atau suku bangsa.

Artinya, sebagai sebuah terminologi multikulturalisme kadang-kadang agak membingungkan karena ia merujuk secara sekaligus pada dua hal yang berbeda, yaitu realitas dan etika atau praktik dan ajaran. Sebagai realitas atau praktik, multikulturalisme dipahami sebagai representasi yang produktif atas interaksi di antara elemen-elemen sosial yang beragam dalam sebuah tataran kehidupan kolektif. Sebagai sebuah etika atau ajaran, multikulturalisme meru-

11 Ibid.

12 Bhiku Parekh, 2007. Rethinking Multikulturalism Keberagaman Budaya dan Teori Politik. Yogyakarta: Kanisius, hal. 3

13 Alo Liliweri, 2005. Prasangka dan Konflik, Komunikasi Lintas Budaya Masyarakat Multikultur. Yogyakarta: LkiS, hal. 6 
juk pada spirit, etos, dan kepercayaan tentang bagaimana keragaman atas unitunit sosial yang berciri privat dan relatif otonom itu, seperti etnisitas dan budaya yang semestinya dikelola dalam ruang-ruang publik. Terhadap perbedaan ini Budiman ${ }^{14}$ berusaha menengahinya dengan mengatakan bahwa Parekh memang tidak merekomendasikan multikulturalisme sebagai doktrin politik, tetapi praktik multikulturalisme memang lebih mudah dilihat dan dipahami dalam konteks kebijakan politik suatu negara. Dengan kalimat lain bahwa kebijakan multikultural dikembangkan menjadi sebuah model pengelolaan perbedaan kultural. Ini menunjukkan bahwa multikulturalisme dalam teori dan praktik memang merupakan gejala yang rumit.

Pada satu sisi multikulturalisme mensyaratkan adanya kesadaran dari setiap individu ataupun kelompok, baik yang didasari atas kesamaan agama, etnis, dan budaya untuk menghargai keberadaan individu ataupun kelompok yang lain. Ini merupakan kondisi ideal suatu masyarakat plural sebagaimana dinyatakan oleh para pemikir multikulturalisme gelombang pertama, yaitu (1) kebutuhan terhadap pengakuan (the need of recognition) dan (2) legitimasi keragaman budaya atau pluralisme budaya. ${ }^{15}$ Artinya, multikulturalisme menjadi kondisi ideal suatu masyarakat, bila keanekaragaman agama, etnis, dan budaya tidak saja diakui, tetapi juga diberikan ruang untuk mengembangkan diri dan mengartikulasikan identitasnya dalam kerangka kesetaraan dan keadilan.

Persoalan kesetaraan dan keadilan inilah yang kemudian menjadi perhatian penting para kritikus multikulturalisme gelombang kedua. Pada masa ini paham multikultural telah menampung berbagai jenis pemikiran baru, seperti culture studies, postkolonialisme, globalisasi, feminisme dan postfeminisme, neo-Marxis, serta poststrukturalisme. Para teoretisi ini memandang bahwa keanekaragaman budaya di masyarakat bukanlah kenyataan yang terberi (given) begitu saja, tetapi sebuah konstruksi sosial yang dipengaruhi sejumlah other. Oleh karenaitu, multikulturalisme haruslah diuraikan dengan mendekonstruksi persoalan-persoalan ideologi, kekuasaan, marjinalisasi budaya, keadilan, politik, ekonomi, gender, permainan wacana, dan emansipasi budaya yang

14 Hikmat Budiman, (ed). 2005. Hak Minoritas Dilema Multikulturisme di Indonesia. Jakarta: Yayasan Interseksi/The Interseksi Foundation, hal. 5

15 H.A.R. Tilaar, 2004. Multikulturalisme Tantangan-tantangan Global Masa Depan dalam Transformasi Pendidikan Nasional. Jakarta: Grasindo, hal. 84 
mengitarinya. ${ }^{16}$ Artinya, multikulturalisme akan mendapatkan makna yang sesungguhnya hanya dengan memproklamasikan emansipasi budaya-budaya kecil yang masing-masing memiliki "hak hidup" yang wajib dihormati.

Dengan demikian, dapat dipahami bahwa Indonesia sebagai sebuah negara-bangsa yang multietnis dan multikultural sudah sejak awal mengandung masalah legitimasi kultural karena negara Indonesia lahir secara tiba-tiba melalui revolusi politik nasional. Akibatnya, kehadiran negara di Indonesia merupakan hasil kolektif hampir seluruh daerah dan kelompok etnis yang mengitarinya. Keadaan ini secara keseluruhan telah menciptakan status yang sama di semua daerah sehingga hubungan antardaerah lebih bersifat kolegial daripada superior-subordinat. Apalagi akar nasionalisme Indonesia sejak awal justru didasarkan pada tekad yang menekankan pada pentingnya cita-cita bersama, di samping pengakuan sekaligus penghargaan pada perbedaan sebagai pengikat kebangsaan. Kesadadaran semacam itu jelas terlihat pada semboyan Bhinneka Tunggal Ika yang menekankan pada pentingnya cita-cita yang sama dan sekaligus kemajemukan sebagai perekat kebangsaan. Pada prinsipnya etika ini meneguhkan pada pentingnya komitmen negara untuk memberi ruang bagi kemajemukan pada satu pihak dan pada pihak lain tercapainya cita-cita kemakmuran dan keadilan sebagai wujud dari tujuan nasionalisme Indonesia. ${ }^{17}$ Dalam konteks inilah diperlukan upaya serius dan sungguh-sungguh untuk segera mentransformasikan kesadaran multikulturalisme menjadi identitas nasional menuju terwujudnya kesatuan Indoensia. Kesadaran baru ini berlaku untuk seluruh komponen bangsa sehingga memiliki peran yang sama dalam pembentukan negara-bangsa Indonesia. Dengan demikian, semuanya memiliki hak yang sama untuk hidup dan menikmati hasil-hasil pembangunan secara adil dan merata.

Persoalan ini menjadi semakin rumit ketika sejarah bangsa telah menorehkan luka sosial-kultural, berupa ketimpangan sosial, ketidakadilan, ketidakmerataan pembangunan, dan tirani minoritas di berbagai daerah di Indonesia. Gerakan-gerakan artikulasi identitas yang mengedepankan sentimen

\section{Ibid., hal. 83-84}

17 Daniel Sparringa, 2006. “Multikulturalisme Indonesia: Nilai-nilai Baru untuk Indonesia Baru (sebuah Jawaban terhadap Kemajemukan)". Makalah disampaikan dalam seminar tentang "Pendidikan Nilai-nilai Kehidupan Ditinjau dari Berbagai Perspektif Ilmu" yang diselenggarakan oleh Universitas Atmajaya, Jakarta, 18 November 2006. 
agama, etnis, dan lokalitas dapat dipandang menjadi kesadaran baru di antara komponen bangsa. Ini merupakan kebanggaan dalam kehidupan berbangsa, ternyata hanyalah banyang-bayang semu. Boleh jadi, hal ini membenarkan pandangan Anderson ${ }^{18}$ yang memaknai bangsa hanyalah sebagai komunitas imajiner (imagined communities). Komunitas politik ini mencakup jutaan orang yang belum pernah terlihat dan mungkin saja tidak akan pernah melihat. Akan tetapi, mereka diharapkan tetap membayar pajak, memberikan pengorbanan, bahkan memberikan nyawanya untuk bangsa. ${ }^{19}$

Ini sebabnya identitas nasional (national identity) memang diperlukan oleh sebuah komunitas politik, seperti negara-bangsa Indonesia. Identitas ini tidak saja untuk membedakannya dengan komunitas yang lain (liyanan), tetapi lebih penting untuk membangun rasa kasih sayang, tanggung jawab, dan kepentingan nasional. Pemahaman tentang identitas nasional menyatukan para anggotanya pada sekitar pemahaman diri, memberi fokus serta energi pada rasa memiliki bersama, membentuk citra diri kolektif, mengolah kebaikan yang relevan, memfasilitasi reproduksi diri komunitas dan kesinambungan antargenerasi, mempertahankan kesetiaan umum, serta menata kehidupan moral dan politik. Singkatnya, identitas nasional memiliki peran penting dalam masyarakat multikultur untuk menumbuhkan perasaan saling memiliki antara komunitas-komunitas yang beranekaragam. ${ }^{20}$ Akan tetapi, identitas nasional memang memiliki sisi dasar yang gelap dan dengan mudah menjadi sumber konflik dan perpecahan. Mengingat kesalahan dalam mendefinisikan identitas nasional dapat berakibat pada pendelegitimasian "yang satu" sekaligus peminggiran "yang lain". Bahaya serius dalam sebuah masyarakat multikultur terjadi dengan keanekaragaman nilai, visi terhadap kehidupan yang baik, dan interpretasi sejarah yang tidak dapat dihindarkan. Dengan demikian, identitas nasional adalah paradoks dalam dirinya sendiri karena terkandung potensi perpecahan dan sekaligus kesatuan. ${ }^{21}$

18 Benedict Anderson, 1999. Komunitas-Komunitas Terbayang Renungan Tentang Asal Usul dan Penyebaran Nasionalisme. Alih Bahasa Omi Intan Naomi. Yogyakarta: Pustaka Pelajar, hal. 21

19 Bhiku Parekh, 2007. Rethinking Multikulturalism Keberagaman Budaya dan Teori Politik. Yogyakarta: Kanisius, hal. 36

$20 \quad$ Ibid., hal.306

$21 \quad$ Ibid., hal.307 
Menyikapi pandangan tersebut logosentrisme menjadi sesuatu yang berbahaya dalam upaya transformasi kesadaran kebangsaan yang multikultur menjadi identitas nasional yang menempatkan persatuan di atas pluralitas. Logosentrisme bertolak dari pandangan Aristoteles yang disebutnya logos apophanticos, yaitu proposisi-proposisi logis. Dijelaskan bahwa proposisi logis haruslah berasal dari identitas asli, jika sesuatu itu " $\mathrm{A}$ ", maka tidak mungkin ia sekaligus "bukan A". ${ }^{22}$ Kemudian, logosentrisme dengan kekuatan logika deduktifnya ini mendapatkan perhatian serius dalam pemikiran Kritis misalnya, Derrida menolak upaya logos dalam merengkuh kebenaran totalitas dengan menepikan perbedaan-perbedaan. ${ }^{23}$ Mengingat pada hakikatnya Logosentrisme itu merupakan penotalan dan pemutlakan satu kebenaran dengan menidakkan yang lain (the others). Derrida dengan tegas menolak pandangan ini dengan mengajukan model analisis dekonstruksi yang lebih menekankan pada kebenaran yang tidak tunggal, melainkan tersebar (difference).

Pemikiran dekonstruksi Derrida pada mulanya bergerak dalam ranah linguistik, tetapi bersamaan dengan trend postmodernisme yang ditandai dengan munculnya gejala dominan pembalikan ke arah bahasa (linguistic turn), pemikiran dekonstruksi Derrida juga banyak digunakan untuk membaca teks sosial dan budaya. Penolakan Derrida terhadap logosentrisme mulanya diarahkan pada kerja positivistik yang berupaya mendapatkan kebenaran tunggal dari sebuah teks sosial. Menurut Derrida, kebenaran tidak selalu mensyaratkan suatu hierarkis (yang satu lebih unggul daripada yang lain) dan beroposisi (ada yang satu, menidakkan yang lain). Derrida memberikan contoh sederhana tentang perbedaan hitam dan puth. Kategori hitam tidak hanya dipakai untuk membedakan dengan yang putih atau menidakkan yang putih karena dapat dibuat kategori yang lain misalnya, abu-abu. Dengan adanya kategori $a b u-a b u$ sebagai yang lain, (the others), kedua kategori sebelumnya (hitam dan putih) tetap seperti sediakala. ${ }^{24}$

Dengan cara kerja ini, juga identitas nasional hendaknya dipandang sebagai teks sosial yang tidak hanya muncul sebagai bentuk penilaian (jugde-

22 I. Bambang Sugiharto, 1996. Postmodernisme Tantangan Bagi Filsafat. Yogyakarta: Kanisius, hal. 122

23 Muhammad Al-Fayyadl, 2005. Derrida. Yogyakarta: LKiS Pelangi Aksara, hal. 76

24 Ibid. 
ment), pernyataan (proposition), dan representasi (representation) ${ }^{25}$ Dalam hal ini identitas nasional bukanlah penilaian, pernyataan, dan representasi kebijakan politik multikulturalisme dengan makna yang univokal dan tidak menyertakan sedikit pun ambiguitas di dalamnya. Dekonstruksi menggugat modus pemaknaan yang terpusat dan cenderung bulat seperti yang mungkin diinginkan oleh teks. Dalam dekonstruksi makna lebih dialami sebagai proses dari penafsiran, bukan hasil yang sudah jadi dan dapat dinikmati begitu saja. Makna teks ada di balik layar, tetapi wujudnya bukan kehadiran, melainkan proses menjadi yang terus-menerus menunda pengertian yang dirasakan memadai dan menggantikannya dengan penanda-penanda baru yang lebih terbuka dan ambigu. ${ }^{26}$ Dengan kata lain bahwa identitas nasional tidaklah sesuatu yang final, tetapi senantiasa menjadi.

Pandangan ini tampaknya sejalan dengan pemikiran Anthony D. Smith ${ }^{27}$ bahwa identitas nasional merupakan kesinambungan reproduksi dan interpretasi atas pola nilai, simbol, mitos, dan tradisi yang membentuk warisan bangsa yang unik, serta identifikasi individu dengan pola dan warisan tersebut beserta unsur-unsur budayanya. Ini berarti bahwa identitas nasional harus terus-menerus diperbaharui dan disesuaikan dengan perkembangan masyarakat yang dikenakan identitas itu. Identitas nasional dibangun atas dasar multikulturalisme dengan menempatkan kebhinnekaan sebagai modal budayaan bangsa untuk maju, mengatasi kesulitan-kesulitan, dan menggalang kekuatan nasional terutama pada era globalisasi. Untuk itu perlu dikenal dasar-dasar multikulturalisme, antara lain menggali kekuatan-kekuatan suatu bangsa yang tersembunyi dalam budaya yang berjenis-jenis. ${ }^{28}$ Modal budaya inilah yang seharusnya digali dan digalang menjadi kekuatan nasional, bukan saja untuk mengokohkan kebudayaan nasional, tetapi lebih penting adalah memberikan tempat yang setara, sejajar, dan adil bagi setiap kebudayaan untuk berpartisipasi aktif dalam pembangunan negara-bangsa.

Berkaitan dengan upaya membagun multikulturalisme di Indonesia ${ }^{29} \mathrm{Ti}$ laar setidak-tidaknya mengemukakan tiga tantangan multikulturalisme dewa-

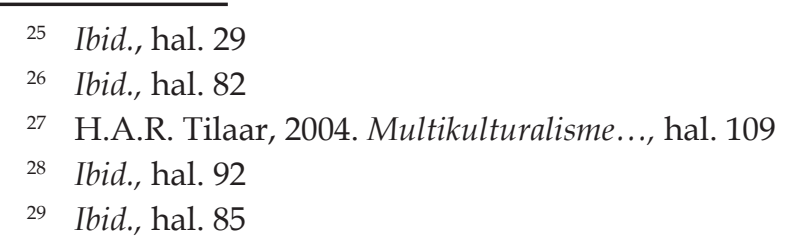


sa ini. Pertama, hegemoni Barat pada bidang politik, ekonomi, sosial, dan ilmu pengetahuan. Hegemoni Barat melalui wacana modernisasi yang disebarluaskan pada negara-negara berkembang bertendensi pada terbentuknya budaya modern yang dibedakan dengan budaya primitif dan barbarian. ${ }^{30} \mathrm{Kedua}$, esensialisasi budaya. Dalam hal ini multikulturalisme berupaya mencari esensi budaya sendiri tanpa jatuh ke dalam pandangan yang xenopobhia dan etnosentrisme. Ketiga, proses globalisasi. Globalisasi dapat berupa monokulturalisme karena gelombang dahsyat globalisasi yang menggelinding menghancurkan bentuk-bentuk kehidupan bersama dan budaya tradisional. Hilangnya jati diri dan identitas budaya lokal memang menjadi ancaman besar globalisasi karena manusia hanya menjadi aktor dan konsumen dari imperialisme baru yang dibawa globalisasi. Tantangan-tantangan tersebut pada dasarnya memiliki tendensi logosentris yang monokultural dan tentu berbahaya bagi pembangunan multikulturalisme di Indonesia terutama bagi kesatuan Indonesia.

Artinya, dewasa ini Indonesia masih berhadapan dengan berbagai tantangan dalam upaya membangun multikulturalisme. Untuk menghadapi tantangan tersebut Sparringa ${ }^{31}$ mengajukan upaya penafsiran terhadap nasionalisme Indonesia yang semestinya memperhatikan dua elemen dasar secara sekaligus. Ikatan kebangsaan yang semata-mata didasarkan pada nilai-nilai kemakmuran (yang bersifat material) dan keadilan (yang bersifat spiritual) tidak akan sepenuhnya mampu menjawab persoalan tentang bagaimana kemajemukan itu hendak dikelola dalam proses pencapaian tujuan bersama. Pencapaian tujuan bersama jelas merupakan sebuah proses yang tidak saja kompleks secara ekonomi dan politik, tetapi juga sebuah proses yang panjang dan berkelanjutan secara sosial dan budaya. Dalam konteks inilah pemaknaan tunggal terhadap identitas nasional telah menciptakan luka sejarah yang mendalam. Indonesia telah melewati masa-masa sulit dengan model nasionalisme politik yang diterapkan beberapa orde pemerintahan. Misalnya, phobia Orde Baru telah mendorong pemerintahan masa pascareformasi membuat kebijakan otonomi daerah sampai ke tingkat kabupaten/kota yang berakibat pada munculnya hiperotonomi. Kelemahan otonomi daerah inilah yang direorientasi dan direvitalisasi sejalan

30 Samuel P Hutington, 2003. Benturan Antarperadaban dan Masa Depan Politik Dunia. Yogyakarta: Qalam, hal. 77

31 Daniel Sparringa, 2006. “Multikulturalisme..., hal. 3 
dengan spirit multikulturalisme sehingga menjadi kekuatan yang fungsional untuk membangun kesatuan Indonesia.

\section{Agama dan Mulkulturalisme}

Agama seringkali bersifat paradoks, pada satu sisi agama dijalani sebagai jalan penjamin menuju keselamatan, cinta, dan perdamaian. Sementara itu, pada sisi lainnya agama justru menjadi sumber penyebab dan alasan bagi kehancuran dan kemalangan umat manusia. ${ }^{32}$ Mungkin ungkapan yang menyatakan bahwa manusia akan hidup lebih baik dan tertib serta bahagia, jikalau hidupnya tanpa agama, seolah-olah benar adanya. Oleh karena agama orang bisa saling mencinta, tetapi juga atas nama agama orang bisa saling membunuh dan menghancurkan. ${ }^{33}$ Sampai di sini agama tampaknya plin-plan terhadap eksistensi manusia, agama menyebabkan kebahagiaan sekaligus agama menyebabkan kesengsaraan; atau agama yang menyebabkan dan menciptakan kedamaian dan kelestarian, tetapi juga agama yang menyebabkan peperangan dan kehancuran. Sampai di sini, agama merupakan realitas sosial yang berwajah ganda.

Menempatkan agama sebagai satu-satunya penyebab terjadinya konflik sosial memang tidak seluruhnya benar karena penyebab konflik sangatlah kompleks. Akan tetapi, ketika agama dilibatkan dalam suatu konflik hal ini sangat beralasan mengingat peran agama berikut:

"Agama memang merupakan wahana yang sangat efektif untuk memobilisasi massa. Namun keefektifan agama sebagai penyebab suatu konflik tergantung pada kondisi yang dialami sebuah masyarakat. Agama akan mudah menjadi wahana mobilisasi guna mencapai tujuan negatif, seperti penyebab konflik, apabila masyarakat mengalami ketidakberdayaan ekonomi dan politik yang tinggi. Sebaliknya, agama akan sulit dijadikan penyebab konflik bila keberdayaan ekonomi dan politik masyarakat tinggi" ${ }^{34}$

Artinya, ada hubungan yang erat antara agama, ekonomi, dan politik sebagai sumber konflik sosial. Dalam kaitan ini agama setidak-tidaknya efektif un-

32 Dadang Kahmad, 2002. Sosiologi Agama. Bandung: Remaja Rosdakarya, hal. 147

33 Charles Kimball, 2003. Kala Agama Jadi Bencana. Bandung: PT.Mizan, hal. 13

34 L. Soetrisno, 2003. Konflik Sosial Studi Kasus Indonesia. Yogyakarta: Tajidu Press, hal. 
tuk menumbuhkan sentimen keagamaan dalam diri penganutnya sehingga dapat dengan mudah ditunggangi oleh kepentingan lainnya, baik politik maupun ekonomi. Pada satu sisi agama merupakan sesuatu yang pribadi berkelindan dengan keyakinan manusia dalam hubungannya dengan Yang Sakral. Akan tetapi, pada sisi yang lain, juga agama melibatkan diri dalam berbagai konteks kehidupan sosial praktis individu dan masyarakat. Malahan agama telah memasuki kancah kehidupan masyarakat di luar batas agama, seperti kebaikan yang diperjuangkannya. Agama bukan saja terlibat dalam urusan batas-batas baik dan buruk, tetapi agama telah memasuki wilayah publik untuk menentukan batas-batas wilayah kebudayaan, masyarakat, dan negara. Malahan gejala intelektual belakangan ini menunjukkan bahwa studi-studi agama dilakukan dengan dua pendekatan, yaitu pendekatan theoposentris yang lebih tekstual dan pendekatan sosio-historis yang lebih kontekstual. ${ }^{35}$

Pada dasarnya kedua pendekatan ini menegaskan bahwa agama sebagai realitas sosial sesungguhnya tidak pernah mencapai perkembangannya yang final. Malahan gejala keagamaan menunjukkan terjadinya pembusukan-pembusukan dan pertukaran-pertukaran peran antara agama dan masyarakat. Kimball ${ }^{36}$ menyebutkan ada lima hal yang menyebabkan agama menjadi busuk dan korup - berubah fungsi. Pertama, apabila suatu agama mengklaim kebenaran agamanya sebagai kebenaran yang mutlak dan satu-satunya. Kedua, adalah ketaatan buta kepada pemimpin keagamaan mereka. Ketiga, apabila agama mulai ganderung merindukan zaman ideal, lalu bertekad merealisasikannya pada zaman sekarang. Keempat, apabila agama tersebut membenarkan dan membiarkan terjadinya "tujuan yang membenarkan cara". Kelima, bila agama tidak segan-segan memekikkan perang suci. Bila indikasi-indikasi tersebut semakin menonjol dalam kalangan umat beragama dapat diasumsikan bahwa institusi keagamaan telah gagal dalam perannya sebagai mediator dalam menyampaikan ajaran-ajaran kesucian agama kepada para pemeluknya.

Pandangan serupa juga dapat dirujuk dalam tesis yang dikemukakan J. M. Hull tentang religionisme dan/atau agamaisme. Religionisme dan/atau agamaisme dimaksudkan adalah isme atau ideologi - serupa seperti rasisme

35 Roland Robertson, 1988. Agama: Dalam Analisas dan Interpretasi Sosiologi, Jakarta: Rajawali, hal. xvii

36 Charles Kimball, 2003. Kala..., hal. 24-25 
- yang meyakini bahwa agama milik sendirilah yang satu-satunya benar dan valid, sedangkan agama yang lain salah. ${ }^{37}$ Paham ini cenderung mendorong para penganutnya pada solidaritas tribalistik. Identitas yang digunakan oleh agamaisme bersandar pada sikap penolakan atau eksklusivisme atau ketertutupan. Hubungan antara "kami" dan "mereka" dibangun dalam kerangka dikotomis yang beroposisi biner, seperti "baik-buruk", "selamat-laknat", "beriman-kafir", dan seterusnya. Keberadaan "mereka" senantiasa dipandang mengancam eksistensi "kami". Eksklusivisma agama tidak jarang diikuti dengan tindakan kekerasan terhadap penganut agama lain, baik kekerasan fisik maupun kekerasan simbolik.

Menurut Hull bahwa pandangan agamaisme bukan semata-mata karena tipe kepribadian atau corak beragama individu. Agamaisme memiliki akar sosio-historis dalam ideologi yang dianut masyarakat dan dilanggengkan oleh lembaga-lembaga agen sosialisasi. Secara spesifik, Hull mengarahkan kritiknya pada pendidikan agama di sekolah yang hanya mengajarkan tentang agama yang dipeluk murid, bukan tentang agama yang berkembang di lingkungan sekitar murid atau lebih luas lagi di dunia. Di sini Hull menekankan pentingnya pendidikan agama sebagai fondasi yang menentukan sikap dan pandangan seseorang terhadap ajaran agamanya dalam konteks multikulturalisme.

Dalam konteks pendidikan agama di Indonesia hal ini dapat dicermati dengan masih adanya peminggiran ilmu-ilmu sosial dan humaniora di mana pendidikan agama merupakan salah satu bagian pentingnya. Kenyataan ini terlihat pada penghargaan yang berlebihan kepada ilmu-ilmu murni yang bersifat positivistik daripada ilmu-ilmu sosial dan humaniora. Ilmu-ilmu sosial dan humaniora hanya dipandang sebagai pelengkap karena dipandang kurang menjamin masa depan anak didik. ${ }^{38}$ Pendidikan agama selama ini hanya sebatas mengajarkan ajaran agama secara skriptural (sesuai doktrin-doktrin dalam kitab suci) dan kurang kontekstual sehingga kurang teraplikasikan dalam ke-

37 Maulanusantara. 2008. "Menepis Prasangka, Memupuk Toleransi Untuk Multikulturalisme". Artikel dalam maulanusantara.wordpress.com, posting 30 April 2008. Lihat juga Rato Rano, 2010. "Religionisme" dan Urgensi Perubahan Paradigma Pendidikan Agama". Artikel dalam m.kompasiana.com, posting 28 April 2010.

38 Kautsar Azhari Noer, 2005. "Pluralisme dan Pendidikan di Indonesia, Menggugat Ketidakberdayaan Sistem Pendidikan Agama dalam Pluralisme, Konflik dan Pendidikan Agama di Indonesia". Yogyakarta : Pustaka Pelajar 
hidupan nyata. Ajaran-ajaran agama yang termuat dalam kitab suci semestinya dapat ditransformasikan menjadi agama sosial, yaitu internalisasi ajaran agama yang selanjutnya dipraktikkan dalam kehidupan nyata sebagai pedoman perilaku. ${ }^{39}$ Malahan Ilmu Perbandingan Agama yang diajarkan di perguruan tinggi seringkali hanya dijadikan untuk menunjukkan unit-unit kelemahan dalam ajaran agama lain dan menunjukkan keunggulan agama sendiri. Untuk mengatasi hal tersebut Hull merekomendasikan tiga strategi untuk mewujukan multikulturalisme agama seperti berikut.

Pertama, mengganti agamaisme dengan tradisi spiritual yang asli (genuine) dan otentik sambil mengupas bias sejarah dan politik yang divisif sejalan dengan model pendekatan konteksual dalam pendidikan agama. Radakrishnan menjelaskan bahwa hakikat agama merupakan suatu panggilan menuju suatu petualangan spiritual. Agama bukan hanya urusan teologi, melainkan agama lebih menjadi disiplin tindakan. Hakikat agama tidak terletak pada dogmadogma dan kredo-kredo, ritus-ritus, dan upacara-upacara yang menjemukan, tetapi kebijaksanaan-kebijaksanaan paling mendalam dari segala zaman. Spiritualisme mengatasi otoritas dan konformitas institusi agama, ia berdiri di luar semua agama. ${ }^{40}$ Oleh karena itu, Radakrishnan menjelaskan bahwa perbedaan antaragama bukan menyangkut kebenaran, melainkan pandangan-pandangan atau pemahaman terhadap kebenaran yang diyakini. Agama-agama pada dasarnya merupakan wujud-wujud historis yang berbeda-beda dari satu kebenaran yang validitasnya bersifat universal dan tidak berkesudahan. Dalam spiritualitas perbedaan agama tidak akan menghalangi visi suci manusia untuk menemukan kediriannya di tengah-tengah alam semesta.

Kedua, menekankan bahwa tujuan universal agama-agama adalah sama, yaitu menghadirkan spirit Tuhan di bumi dan menciptakan surga di muka bumi. Transfigurasi atau spiritualisasi dalam pandangan eksistensialis Nietszchean ${ }^{41}$ merupakan cara untuk mewujudkan eksistensi manusia, yakni kebebasan spirit dalam bentuk moral dan kemanusiaan. Nietzsche membangun

39 Thomas F O'Dea, 1985. Sosiologi Agama. Jakarta: CV. Rajawali. Lihat juga Elizabeth K Nottingham, 1985. Agama dan Masyarakat. Jakarta: CV.Rajawali. Lihat juga Betty R Scharf, 1995. Kajian Sosiologi Agama. Yogyakarta: CV.Tiara Wacana

40 Roland Robertson, 1988. Agama: Dalam Analisas dan Interpretasi Sosiologi, Jakarta: Rajawali, hal. 113

$41 \quad$ Ibid., hal. 112 
gagasan spiritualitas postreligiusnya secara ekstrim bahwa kebebasan spirit diperoleh melalui "perahmatan" yang bukan hanya milik Tuhan dan wakilwakil Tuhan di dunia-kehidupan, melainkan transfigurasi. Manusia bisa menjadikan dirinya "tuhan", bila berhasil melakukan transfigurasi praktik hidup ketuhanan. Boleh jadi, Nietzsche ingin menyampaikan pentingnya transformasi kesadaran ketuhanan (divine consciousness) menjadi kesadaran kemanusiaan (human consciousness), dalam kalimat yang lebih lunak. Dengan demikian, setiap manusia, apapun agamanya, memiliki kesempatan yang sama untuk memperoleh pencerahan dan rahmat di dunia ini.

Ketiga, mengganti dakwah dan misionaris agamaisme yang cenderung menghujat agama lain dan mengkonversi pemeluk agama lain dengan dakwah agama otentik dan misi agama yang paling menyelamatkan serta bertujuan untuk menegakkan keadilan dan perdamaian, serta menghadirkan Tuhan dalam kehidupan fana manusia. Rekomendasi ini bertali-kelindan dengan rekomendasi sebelumnya bahwa agama hanyalah sarana untuk menuju Tuhan, bukan Tuhan itu sendiri. Tujuan hidup manusia adalah Tuhan yang bersama-sama dicari dalam agama-agama. ${ }^{42}$ Melalui kesadaran ini antarumat beragama tidak akan saling hujat-menghujat, mati-matian membela agamanya yang seolaholah membela Tuhannya, dan menawarkan satu-satunya keselamatan kepada orang lain dengan tujuan konversi agama. Dengan demikian, agama dapat dijadikan instrumen untuk mewujudkan multikulturalisme dan Indonesia persatuan, bukan sebaliknya menjadi alat pemecah belah persatuan.

Berdasarkan tiga strategi di atas dapat dipahami bahwa agama tidaklah mungkin menjadi agama dominan dari agama lainnya karena sama-sama mengajarkan kebaikan ketuhanan, kemanusiaan, dan kealaman. Oleh karena itu, untuk mewujudkan multikulturalisme agama di Indonesia diperlukan upaya kerjasama antaragama dalam rangka membangun dan menata perubahan nilai sosial yang bersumber dari agama itu sendiri. Faktanya bahwa agama sebagai sumber dari dan inti kebudayaan nasional, sebagaimana dikembangkan melalui Pancasila dan yang lebih dikenal dengan semboyan bhineka tunggal ika. Inilah landasan kehidupan keagamaan di Indonesia, bila semua aspek bangsa menghendaki keamanan dan kenyamanan sosial dalam kebersamaan

42 Eusta Supono, 2002. Agama Solusi atau Ilusi? Kritik atas Kritik Agama Karl Marx. Yogyakarta: Komunitas Studi Didaktika, hal. 73 
dalam kerangka multikulturalisme. Artinya, multikulturalisme agama di Indonesia akan dapat terwujud dengan sentosa, bila semua agama menerima dan mengapresiasi Pancasila dan Bhineka tunggal ika menjadi landasan sosial keagamaannya.

\section{Penutup}

Pada akhirnya dapat dipahami bahwa mewujudkan peran agama dalam mewujudkan multikulturalisme di Indonesia dapat ditempuh setidak-tidaknya melalui upaya transformasi kesadaran multikulturalisme menjadi identitas nasional dengan bertumpu pada penghargaan terhadap kepluralistikan masyarakat Indonesia. Untuk itu Bhinneka Tunggal Ika sebagai teks ideal senantiasa perlu dibaca ulang pada setiap zaman karena pada prinsipnya identitas tidak pernah final. Begitu juga, upaya membangun integrasi nasional yang berbasis multikulturalisme dengan mendorong kesadaran masyarakat menggunakan hak konstitusinya dalam berkumpul, berserikat, dan berpendapat guna memperjuangkan hak-hak keadilan, kebebasan, kesetaraan, serta berpartisipasi aktif dalam pembangunan. Kemudian, mendorong pemerintah menjadikan civil society sebagai mitra kerja, baik dalam pengambilan kebijakan dan ekskusinya pada bidang-bidang yang menyangkut hajat hidup masyarakat dengan tetap memperhatikan entitas-entitas budaya lokal. Pada akhirnya, mendorong peran agama dalam kehidupan sosial dan kebudayaan misalnya, dengan menegaskan bahwa tujuan hidup manusia adalah Tuhan, bukan agama. Melalui kesadaran ini, antarumat beragama tidak saling menghujat, mati-matian membela agamanya yang seolah-olah membela Tuhannya, dan menawarkan keselamatan kepada orang lain dengan tujuan konversi agama. Dengan demikian, agama menjadi pemersatu bagi seluruh masyarakat dan tidak sebaliknya menjadi alat pemecah belah persatuan Indonesia.

\section{DAFTAR PUSTAKA}

Anderson, Benedict, 1999. Komunitas-Komunitas Terbayang Renungan Tentang Asal Usul dan Penyebaran Nasionalisme. Alih Bahasa Omi Intan Naomi. Yogyakarta: Pustaka Pelajar.

Atmadja, Nengah Bawa, 2005, “Bali Pada Era Globalisasi: Pulau Seribu Pura 
Tidak Seindah Penampilannya" (hasil penelitian - studi kasus pada berbagai desa), Singaraja:-

Azra, Azyumardi. 2011. "Culture of Violence in the Name of Religion". Makalah. Disampaikan dalam Seminar dengan tema "Agama dan Kekerasan" pada Program Pascasarjana Universitas Hindu Indonesia (UNHI) Denpasar.

Budiman, Hikmat (ed). 2005. Hak Minoritas Dilema Multikulturisme di Indonesia. Jakarta: Yayasan Interseksi/The Interseksi Foundation.

Fayyadl, Muhammad Al-. 2005. Derrida. Yogyakarta: LKiS Pelangi Aksara.

Hefner, Robert W. 2007. Politik Multukulturalisme: Menggugat Realitas Kebangsaan. Yogyakarta: Kanisius.

http:/ / tilemkajeng-sanurbali.blogspot.com/2012/03/agama-dan-multikultur. html

Hutington, Samuel P. 2003. Benturan Antarperadaban dan Masa Depan Politik Dunia. Yogyakarta: Qalam.

Kahmad, Dadang. 2002. Sosiologi Agama. Bandung: Remaja Rosdakarya Kimball, Charles.2003. Kala Agama Jadi Bencana. Bandung: PT.Mizan.

Kusumohamidjojo, Budiono, 2000, Kebhinnekaan Masyarakat Indonesia: Suatu Problematik Filsafat Kebudayaan, Jakarta: PT. Grasindo.

Liliweri, Alo.2005. Prasangka dan Konflik, Komunikasi Lintas Budaya Masyarakat Multikultur. Yogyakarta: LkiS.

Maulanusantara. 2008. “Menepis Prasangka, Memupuk Toleransi untuk Multikulturalisme". Artikel dalam maulanusantara.wordpress.com, posting 30 April 2008.

Mulkhan, Abdul Munir. 2007. “The Others dalam Bhineka Berbangsa dan Beragama" (Makalah disampaikan pada Seminar Nasional "Multikulturalisme, Agama dan Etnisitas" diselenggarakan oleh Magister Ilmu Agama dan Kebudayaan Universitas Hindu Indonesia di Denpasar tanggal 10 Agustus 2007).

Noer, Kautsar Azhari. 2005. “Pluralisme dan Pendidikan di Indonesia, Menggugat Ketidakberdayaan Sistem Pendidikan Agama dalam Pluralisme, Konflik dan Pendidikan Agama di Indonesia". Yogyakarta: Pustaka Pelajar.

Nottingham, Elizabeth K. 1985. Agama dan Masyarakat. Jakarta: CV. Rajawali. 
Nurkhoiron, M. 2007. "Minoritisasi dan Agenda Multikulturalisme di Indonesia: Sebuah Catatan Awal", dalam Hak Minoritas Multikulturalisme dan Dilema Negara Bangsa. Editor: Marsudi Noorsalim, dkk. Jakarta: Yayasan Interseksi/The Interseksi Foundation.

O'Dea, Thomas F. 1985. Sosiologi Agama. Jakarta: CV. Rajawali.

Parekh, Bhiku. 2007. Rethinking Multikulturalism Keberagaman Budaya dan Teori Politik. Yogyakarta: Kanisius.

Piliang, Y. A. 2003. Hipersemiotika Tafsir Cultural Studies atas Matinya Makna. Yogyakarta: Jalasutra.

Prasetyo, Hendro, dkk. 2008. Islam \& Civil Society Pandangan Muslim Indonesia. Jakarta: Gramedia Pustaka Utama bekerjasama dengan PPIM-IAIN Jakarta.

Radhakrishnan, S. 2003. Religion and Society. Denpasar: Program Magister Ilmu Agama dan Kebudayaan, Universitas Hindu Indonesia Denpasar bekerjasama dengan penerbit Widya Dharma.

Rano, Rato. 2010. “Religionisme" dan Urgensi Perubahan Paradigma Pendidikan Agama". Artikel dalam m.kompasiana.com, posting 28 April 2010.

Robert, Tyler T. 2002. Spiritualitas Postreligius Eksplorasi Hermeneutis Transfigurasi Agama dalam Praksis Filsafat Nietzsche. Yogyakarta: Qalam.

Robertson, Roland. 1988. Agama: Dalam Analisas dan Interpretasi Sosiologi, Jakarta: Rajawali.

Scharf, Betty R.1995. Kajian Sosiologi Agama. Yogyakarta: CV. Tiara Wacana Soetrisno, L. 2003. Konflik Sosial Studi Kasus Indonesia. Yogyakarta: Tajidu Press.

Sparringa, Daniel. 2006. "Multikulturalisme Indonesia: Nilai-nilai Baru untuk Indonesia Baru (sebuah Jawaban terhadap Kemajemukan)". Makalah disampaikan dalam seminar tentang "Pendidikan Nilai-nilai Kehidupan Ditinjau dari Berbagai Perspektif Ilmu" yang diselenggarakan oleh Universitas Atmajaya, Jakarta, 18 November 2006.

Suaedy, Ahmad, dkk. 2007. Politisasi Agama dan Konflik Komunal Beberapa Isu Penting di Indonesia. Jakarta: The Wahid Institute.

Sugiharto, I. Bambang. 1996. Postmodernisme Tantangan Bagi Filsafat. Yogyakarta: Kanisius.

Sukarma, I Wayan. 2010. "Multikulturalisme dan Kesatuan Indonesia” (Dharmasmrti, Vol.5-10-2011:hal.112). Jurnal Ilmu Agama dan Kebudayaan Hindu, Pascasarjana, UNHI: Denpasar. 
Supono, Eusta. 2002. Agama Solusi atau Ilusi? Kritik atas Kritik Agama Karl Marx. Yogyakarta: Komunitas Studi Didaktika.

Suseno, Franz Magnis. 2005. Berebut Jiwa Bangsa. Jakarta: Kompas.

Tilaar, H.A.R.2004. Multikulturalisme Tantangan-tantangan Global Masa Depan dalam Transformasi Pendidikan Nasional. Jakarta: Grasindo. 